Journal of Agriculture and Social Research (JASR) Vol. 8, No. 2, 2008

\title{
ECONOMICS OF SMALL-SCALE PALM OIL PROCESSING IN IKWERRE AND ETCHE LOCAL GOVERNMENT AREAS OF RIVERS STATE, NIGERIA.
}

\author{
EKINE, D. I.* AND ONU, M. E.** \\ *Department of Agricultural Economics and Extension, \\ Rivers State University of Science and Technology, Nkpolu, Port Harcourt, Nigeria. \\ **Department of Agricultural Economics and Extension, \\ University of Port Harcourt, Choba, Port Harcourt, Nigeria
}

\section{ABSTRACT}

Palm oil is one of the most common products used by almost everybody in Nigeria. Small holders constitute the major producers of palm oil in Ikwerre and Etche Local Government Areas. This study was conducted in Ikwerre and Etche Local Government Areas of Rivers State to determine the economic analysis of small-scale palm oil processing in the study area. 93 palm oil processors were randomly selected from 10 Agricultural blocks in Rivers State Agricultural Development Programme. Descriptive statistics, frequencies tables and gross margin model were used for the analysis. The result revealed that the age bracket between 31-40 years $(31.3 \%)$ dominated the palm oil processing enterprise in Ikwerre while the age bracket between 41-50 years (53.3\%) dominated the enterprise in Etche local government area. Majority of the respondents were male in both Ikwerre and Etche local government areas with $62.5 \%$ and $68.9 \%$ respectively. Most of the participants were holders of WASC with $39.6 \%$ and $51.1 \%$ in Ikwerre and Etche L.G.As., respectively. The study revealed that the minimum cost of construction, procurement of equipment and installment of a small scale palm oil processing mill in the two LGAs was estimated to be N873,750 and the cost of processing 1000 Fresh Fruit Palm Bunches (FFPB)was estimated to be N84,000.00 with a gross margin of N16,000.00 including N5,200.00 as the price for the sales of uncracked palm kernel in Ikwerre LGA while in the Etch LGA cost of processing 1000 FFPB was N76,100.00 with a gross margin of N16,000.00 including the sales of uncracked palm kernel of N4,800.00. The sum of N2,988,270.00 and N1,524,420.00 was estimated as the participants monthly gross margin in Ikwerre and Etche LGAs respectively. In order to increase the revenue earnings of the participants in the study area, government should assist them by granting loans and subsidizing cost of buying processing equipment. Also participants should activate small- scale palm oil producers cooperative and make it more functional to earn higher revenue.

Key Words: Small scale palm oil processing

\section{INTRODUCTION}

Palm oil is processed from the fruit of the oil palm (Elaeis guineensis). It is generally agreed that the oil palm originated in the tropical rain forest region of West Africa. The main belt runs through the southern latitudes of Cameroon Co'te d'Ivore, Ghana, Liberia, Sierra Leone, Togo and Congo (Rahman, 1998, FAO 2005). According to them, the primary areas of production are Southeast Asia, followed by the West Coast of Africa and Latin America, oil palm is found in both wild grooves and plantation in Nigeria. Oil palm is indigenous to the Nigerian coastal plain, having migrated inland as a stable crop (Carrere, 2001). He further stressed that oil palm is part of the way of life of millions of Nigerian people.

Plantation farming is a new phenomenon to West African culture and in most of Africa, the farm culture is basically subsistence and small-scale oil palm farm may cover 7.5 hectares (FAO, 2005).

In Nigeria, $80 \%$ of production comes from dispersed small holders who harvest semi- wild plants and use manual processing techniques Carrere, 2005). According to him several million 


\section{Journal of Agriculture and Social Research (JASR) Vol. 8, No. 2, 2008}

smallholders are spread over an estimated area of 1.67 million hectares in the southern part of the country.

Processing of oil fresh fruits palm bunches (FFPB) for edible oil has been practiced in Africa for thousands of years and the oil produced, highly coloured and flavoured is an essential ingredient in much of the traditional West African cuisine (FAO, 2005). The report also stated that the traditional method of processing is simple but tedious and inefficient. The farm's production of fruits may be processed by the farmer, using the traditional method of oil extraction or sold to other processors. Among the small -scale producers, palm oil is principally processed by traditional or semi- mechanized methods (Omereji, 2005).

Palm oil is rich in carotenoids (pigments found in plants and animals) from which it derives its deep red colour and the major component of its glycerides is saturated fatty acid palmitic, ( FAO, 2005).

Palm oil has traditionally been and will remain an essential diet of the people of Nigeria. With an ever-growing population, domestic and industrial consumption will continue to be on the increase (Omereji, 2005). According to Vogel 2002, the local demand for palm oil is substantial, it is estimated that for every five people in Nigeria, perhaps two liters of palm oil or more are consumed each month for cooking. It is a common knowledge that most households in Nigeria use this important product for cooking. Palm oil has a diverse array of food and nonfood users with the main ones being the manufacturing of edible fats, soap, candles, tin-plating for iron sheets, fuel for internal combustion engines and greases and lubricants (Armstrong, 1998; Rahman, 1998). According to them, edible fats industry mainly involving margarine, receives the greatest benefit from palm oil, due mainly to its preservation qualities. Nigeria was before 1965, the world leading producer and exporter of palm oil, and has since 1974 ceased to contribute to the export trade in the commodity, largely due to increased domestic demand in palm produce (Omoti, 2003). According to him, expansion in the industry has since then not kept pace with the growing domestic demand to enable the country to re -enter the export trade. Carrere, 2001 stated that during the past decades Nigeria has become a net importer of palm oil. While in the early 1960s, Nigeria's palm oil production accounted for $43 \%$ of the world production. He further stressed that nowadays it only accounts for $7 \%$ of total global output. Vogel, 2002 reported that Nigeria is now an importer, and it is possible the size of this demand may be currently supplied by foreign imports. The economic importance of oil palm crops in third world countries is of great value. Jobs are provided for thousands of villagers who otherwise may not have employment prospect (Armstrong, 1998).

Palm oil processing is one of the major economic activities of the rural people of Ikwerre and Etche Local Government Areas of Rivers State. Processing of the palm fruits into palm oil involves series of activities, which include cutting of the palm bunches, transportation, loading and offloading, stripping; sterilization and oil extraction. Processing fresh fruit palm bunches (FFPB) into palm oil is one of the most difficult activities in traditional palm oil processing in Nigeria (Omereji, 2005). The fresh fruit bunches of oil palm are processed by various people, each method bringing about production of palm oil, palm kernel and perhaps palm kernel oil.

Palm oil processing enterprise is mainly dominated by small scale processors. The methods and techniques of processing are highly traditional. In addition, obsolete equipment is mostly used in processing activities. Among small- scale producers, palm oil is principally processed by traditional or semi- mechanized methods whose system is highly inefficient (Omotoi, 2003). These methods are laborious, time consuming and inefficient, yield very low oil, often of poor quality and more often about $25-75 \%$ of potential palm oil is lost during processing. High cost of processing equipment is a serious problem faced by processors. This problem had discouraged intending processors from establishing their own mills. Therefore majority of the processors resort to hiring of processing equipment and this had resulted to delay in processing of the palm fruits. Those who do not own mills face marketing problems during 


\section{Journal of Agriculture and Social Research (JASR) Vol. 8, No. 2, 2008}

the peak season when fruit is abundant and processors do not have to forage for raw material (FAO, 2005).

Profit is a major indicator of viability of any business. The amount of revenue realized and operating cost of a business enterprise determines how much gain or loss an enterprise can achieve within a certain period. The determination of the producer's margin is difficult in the small scale palm oil enterprise since producers have several objectives including meeting their consumption need. The quantity and amount of revenue realized by the processors are usually under estimated mainly due to inadequate recording and improper accounting procedures. The level of gross margin of small scale palm oil processors is influenced by determinant which include, cost of palm fruits, cost of hiring equipment, transportation of the palm bunches, availability of labour, price of palm oil among others. These determinants are crucial because the survival of the enterprise is highly dependent on these important variables. It is surprise that most of palm oil mills are closed for sometime resulting to irregular supply of the product in the area. It is on this background that this study is initiated to conduct an economic analysis of small- scale palm fruit processing in in Ikwerre and Etche Local Government Areas of Rivers State. The broad objective of the study is to determine economics of small-scale palm oil processing in Ikwerre and Etche local government area.

The objectives of the study include to:

(i) identify the socio-economic attributes of small-scale palm oil processors in the study area;

(ii) estimate the gross margin of small-scale palm oil processing in Ikwerre and Etche Local Government Areas;

(iii) estimate cost of establishing small-scale mills in the study area.

(iv) identify problems encountered by small-scale palm oil processors.

(v) make policy recommendations based on findings.

\section{METHODOLOGY}

This study was conducted in Ikwerre and Etche Local Government Areas of Rivers State. A sample population of one hundred (100) small-scale palm oil processors was selected from zone 3 of the Rivers State Agricultural Development Programme. Five (5) blocks were selected from each Local Government Area and ten small-scale palm oil processors were randomly selected from each block giving a total of 100 processors. The blocks selected include Isiokpo, Elele, Ubima, Omerelu and Apani (in Ikwerre LGA) and Egwi, Igbo, Okehi, Umuechem, and Olakwo (in Etche LGA). Questionnaire and personal interview were used to obtain information from the respondents. One hundred questionnaires were administered to the respondents. However, ninety three (93) of them were retrieved from the respondents and data analysis was based on the ninety three (93) retrieved questionnaires. Descriptive statistics (frequencies and corresponding percentages) and gross margin model were used in analysis of the data. 


\section{Journal of Agriculture and Social Research (JASR) Vol. 8, No. 2, 2008}

Model Specification

Net Income in naira $=$ Total Revenue - Total Cost of Processing of Palm Oil.

Where:

Total revenue in naira $=$ Sales of Palm Oil + Sales of Uncracked Palm Kernel

Total cost $=$ Cost of FFPB + Cost of hiring machine + cost of firewood + cost of transportation + cost of labour + depreciation on equipment + Building

FFPB $\quad=$ Fresh Fruit Palm Bunches

Gross Margin = Total Sales - Total Variable Cost

\section{RESULTS AND DISCUSSION}

The result from the analysis indicates that the highest age bracket of respondents in palm oil processing business in Ikwerre Local Government Area was 31-40 years and 41- 51 and above with $31.3 \%$ each while the age bracket of respondent that dominated the producers mills in Etche Local Government Area was the age bracket between 41-50 years 53.3\%, this implied that the mills were operated by adults who were matured and responsible. The male dominated the mills in both Ikwerre and Etche Local Government Areas. The number of male palm oil processors in the study area was $30(62.5 \%)$ while $18(37.5 \%)$ of them were female. It is an indication that the nature of the operations does not encourage women participation. The household size of the respondents in the business in Ikwerre Local Government Area was dominated by $6-10$ persons with $58.3 \%$ while that of Etche Local Government Area was dominated by the household size of $0-5$ persons with $46.7 \%$. Its implication is that the family would supply part of labour needed in the milling operations.

Table 1: Socio-economic Characteristics of the Respondents

\begin{tabular}{lcccc}
\hline Age & \multicolumn{2}{c}{ Ikwerre LGA $(\mathrm{n}=48)$} & \multicolumn{2}{c}{ Etche LGA $(\mathrm{n}=45)$} \\
\hline & Frequency & $\%$ & Frequency & $\%$ \\
$21-30$ & 7 & 14.6 & 3 & 6.7 \\
$31-40$ & 15 & 31.3 & 3 & 6.7 \\
$41-50$ & 11 & 29.9 & 24 & 53.3 \\
$51 \&$ above & 15 & 31.3 & 15 & 33.3 \\
Gender & & & & \\
Male & 30 & 62.5 & 31 & 68.9 \\
Female & 18 & 37.5 & 14 & 31.1 \\
Household & & & & \\
Size & & & & \\
$0-5$ & 17 & 35.4 & 21 & 46.7 \\
6-10 & 28 & 58.3 & 19 & 42.2 \\
$11-15$ & 1 & 2.1 & 3 & 6.7 \\
16-20 & 2 & 4.2 & 2 & 4.4 \\
20 \& above & - & - & - & - \\
Educational & & & & \\
Qualification & & & & \\
Higher degree & 11 & 29.9 & 4 & 8.8 \\
First degree & 7 & 14.6 & 4 & 8.8 \\
OND & 4 & 8.3 & - & - \\
WASC & 19 & 39.6 & 23 & 51.1 \\
FSLC & 7 & 14.6 & 5 & 11.1 \\
Below FSLC & - & - & 9 & 20 \\
Illiterate & - & - & - & - \\
\hline SOurce: Field Survey & 2002 & & & \\
\hline
\end{tabular}

Source: Field Survey 2002 
Journal of Agriculture and Social Research (JASR) Vol. 8, No. 2, 2008

Table 2: Average cost of Processing 1000 FFPB in Ikwerre Local Government Area

\begin{tabular}{llrl}
\hline S/No. & Type of operation & Cost(N) & Percentage \\
\hline 1. & FFPB & $52,000.00$ & 61.9 \\
2. & Rent on Machine & $3,500.00$ & 4.2 \\
3. & Firewood/Water & $1,000.00$ & 1.2 \\
4. & Transportation & $10,000.00$ & 11.9 \\
5. & Labour & $4,000.00$ \\
i) & Broaking of FFPB & $10,000.00$ \\
ii) & Separating of fruits & 500.00 \\
iii) & Loading bound for boiling & \\
iv) & Loading into digester/pressing & $3,000.00$ & \\
& Sub-total & $17,500.00$ & 20.8 \\
& \multicolumn{2}{c}{ Total Cost } \\
\hline
\end{tabular}

Quantity of Palm Oil Produced

Producer Price at

Gross revenue

N100,000.00

$\mathrm{N} 2,000.00$ per 20 litre

Net revenue

$\mathrm{N} 16,000.00$

4 barrels of uncracked palm kernel at N1,300 per barrel $\quad \mathrm{N} 5,200 \times 4$

$$
=\mathrm{N} 21,200.00
$$

Table 3: Average cost of processing 1000 FFPB in Etche Local Government Area

\begin{tabular}{|c|c|c|c|c|}
\hline S/No. & Type of Operation & & Cost N & Percentage \\
\hline 1. & FFPB & & $52,000.00$ & 65.7 \\
\hline 2. & Hire of machine & & $3,500.00$ & 4.6 \\
\hline 3. & Firewood/water & & 100.00 & 0.1 \\
\hline 4. & Transportation & & $12,000.00$ & 15.8 \\
\hline 5. & Labour & & & \\
\hline i) & Breaking of palm bunches & & $4,000.00$ & \\
\hline ii) & $\begin{array}{l}\text { Separating (stripping) of fruits } \\
\text { bunches }\end{array}$ & from the & $3,000.00$ & \\
\hline iii) & Loading into barrel & & 500.00 & \\
\hline \multirow[t]{3}{*}{ iv) } & Loading into digester/pressing & & $3,000.00$ & \\
\hline & Sub-Total & & $10,500.00$ & 13.8 \\
\hline & Total & $\mathrm{N}$ & $76,100.00$ & \\
\hline
\end{tabular}

Quantity of palm oil

Gross revenue at N1,800.00 per 20-litre

Net revenue

4 barrel of uncracked kernel at N1,200

Total $=\quad 1000$ litre (tone)

$=\quad \mathrm{N} 90,000.00$

$=\quad 13,900.00$

$4,800.00$

$=\quad \mathrm{N} 18,700.00$

Source: Field Survey 2002 
Journal of Agriculture and Social Research (JASR) Vol. 8, No. 2, 2008

Table 4: Average Monthly Revenue of the Respondents

\begin{tabular}{lllllr}
\hline L.G.A. & Type & $\begin{array}{l}\text { Quantity } \\
\text { Produced }\end{array}$ & Cost N & Sales N & Net Revenue \\
\hline Ikwerre & Palm Oil & 42,760 litres & $610,000.00$ & $3,420,430.00$ & $2,810,430.00$ \\
& & & & $177,840.00$ & $177,840.00$ \\
& Unkracked & $65,664 \mathrm{~kg}$. & & & \\
& Palm & & & Total & $2,988,270.00$ \\
& kernel & & & $1,855,540.00$ & $1,425,540.00$ \\
Etche & Palm Oil & 25,600 litres & $430,000.00$ & & $98,880.00$ \\
& Unkracked & $39,552 \mathrm{~kg}$. & & & $1,524,420.00$
\end{tabular}

Source: Field Survey 2002.

Table 5: $\quad$ Average cost for the procurement of palm oil mill Equipment for small-scale processing

\begin{tabular}{lr}
\hline Items & Amount N \\
\hline Oil presser & $20,000.00$ \\
Digester & $20,000.00$ \\
Barrel & $12,000.00$ \\
1 tank & $20,000.00$ \\
1 head pan & 350.00 \\
1 wheel barrow & $3,000.00$ \\
7 hand glove & 200.00 \\
7 bucket @ & 250.00 \\
4 turning fork & 450.00 \\
Shovel & 500.00 \\
Building construction & $400,000.00$ \\
Cost of land & $400,000.00$ \\
& $873,750.00$ \\
\hline
\end{tabular}

Source: Field Survey 2002

Table 6: Problems encountered by the Respondents.

\begin{tabular}{|c|c|c|c|c|}
\hline \multirow[t]{2}{*}{ Types of problem } & \multicolumn{2}{|c|}{ Ikwerre LGA } & \multicolumn{2}{|c|}{ Etche LGA } \\
\hline & Freq & $\%$ & Freq. & $\%$ \\
\hline Bad state of feeder roads for evacuation of FFPB & 30 & 25 & 35 & 26.7 \\
\hline $\begin{array}{l}\text { Inadequate fund for procurement processing } \\
\text { equipment }\end{array}$ & 45 & 37.5 & 40 & 30.5 \\
\hline Not having access to credit facilities & 25 & 20.8 & 41 & 31.3 \\
\hline Scarcity of labour in the study area & 20 & 16.7 & 15 & 11.5 \\
\hline Total & 120 & 100 & 131 & 100 \\
\hline
\end{tabular}

Multiple Responses

Field Survey, 2002 


\section{Journal of Agriculture and Social Research (JASR) Vol. 8, No. 2, 2008}

The analysis of the educational qualification reveals that majority of the respondent had WAEC school certificate with 39.6\% in Ikwerre and 51.1\% in Etche Local Government Areas. The number of the respondents in Ikwerre Local Government Area had higher degree was $11(29.9 \%)$ while $7(14.6 \%)$ had First School Leaving Certificate (FLSC). Whereas, in Etche Local Government Area, four (4) respondents with 8.8\% had higher degree and first degree while about 9 respondents with 20\% could not complete primary six (6). Education had an effect on the overall behaviour of individuals since knowledge is normally acquired through education. Since majority of the palm oil processors in the study area holders of WASC, it is implied that the level of education may have affected the way the enterprise is being managed in the study area.

Estimated Average Cost and Revenue of Processing 1000 Fresh Fruit Palm Bunches (FFPB).

Cost of processing one thousand fresh fruit palm bunches (FFPB) into palm oil in Ikwerre L.G.A as shown in table 2, indicated that a total amount of N84,000.00 was spent on processing of one tone of palm oil using one thousand (1000) fresh fruit palm bunches (FFPB). The average time for the processing of 1000 FFPB was between 3-4 days using manual palm oil machine. Out of $\mathrm{N} 84,000.00$ spent on the processing of one tone of palm oil, cost of palm fruit was N52,000.00 $(61.9 \%)$, cost of hired labour was N17,500.00 (20.8\%) while transportation cost was N10,000.00 (11.9\%) and cost of hiring machine was at N3,500.00 (4.2\%).

The amount of money realized from sales of palm oil was one hundred thousand naira (N100, 000.00), the revenue realized from the sales of un-cracked palm kernel was twenty one thousand naira (N21, 000.00). The total money realized from the processing of the $1000 \mathrm{FFPB}$ was one hundred and twenty one thousand, two hundred naira (N121, 200.00). The gross margin was calculated to be thirty seven thousand, two hundred naira (N37, 200.00).

Palm oil processing in Etche Local Government Area as shown in Table 3, revealed a total cost of seventy -six thousand naira (N76, 100.00) used in processing 1000 FFPB; Out of which $65.7 \%$ was spent on purchase of FFPB while $13.8 \%$ was spent on labour. A total of ninety thousand naira N90, 000.00) was realized from the sales of palm oil, four thousand, eight hundred naira $(\mathrm{N} 4,800.00)$ was realized from the sales of un -cracked palm kernel. Gross margin of twenty thousand, seven hundred naira (N20, 700.00) was calculated as the gross margin in the local government area.

High cost of palm fruit bunches was an indication of insufficient quantity of palm fruit in the study area. Secondly, most of the palm oil processors do not have own oil palm plantation. High cost of labour was likely as a result of obsolete manual machines which require a lot of human effort and short supply of manpower in the study area. High cost of transportation could be as a result of the bad state of feeder roads, and inadequate loading lorry that aid transportation of FFPB, to the mills. The difference in gross margin recorded in the two local government areas could be as a result of different producers' price in the study area. Since there was a positive gross margin in the study area, it is implied that the palm oil processing business is profitable.

Participants Revenue: The result from table 4, shows that the average monthly revenue of respondents realized from the sales of palm oil in Ikwerre local government area was three million, four hundred and twenty thousand, four hundred and thirty naira (N3, 420,430.00), one hundred and seventy seven thousand, eight hundred and forty naira (N177, 840.00) was realized from the sales of un-cracked palm kernel. A total revenue of three million, five hundred and ninety eight thousand, two hundred and seventy naira $(\mathrm{N} 3,598,270.00)$ was realized by the respondents in the local government area. Cost of processing of the palm fruit was six hundred and ten thousand naira (N610, 000.00) while the gross margin was two million, nine hundred and eighty eight thousand, two hundred and seventy naira (N2, 988,270.00), while in Etche Local Government Area, total revenue realized by the respondents was one million, nine 


\section{Journal of Agriculture and Social Research (JASR) Vol. 8, No. 2, 2008}

hundred and fifty four thousand, four hundred and twenty naira (N1, 954,420.00). Out of which one million, eight hundred and fifty five thousand, five hundred and forty naira $(\mathrm{N} 1,855,540.00)$ was realized from sales of palm oil while sales from un-cracked palm kernel was nine eight thousand, eight hundred and eight hundred and eighty naira (N98,880.00). Cost of processing was four hundred and thirty thousand naira (430,000.00). A gross margin was one million, five hundred and twenty four thousand, four hundred and twenty naira $(\mathrm{N} 1,524,420.00)$ realized.

The result as shown in table 5, revealed that the average cost of establishing a small-scale palm oil processing mill of capacity of 100 litres of palm oil per day was eight hundred and seventy three thousand, seven hundred and fifty thousand naira ( N873,750.00). The huge sum of money required for the establishment of small-scale processing mills in the study area could be the reason why some processors do not own processing mills.

The result on table 6 revealed that among problems faced by the respondents in the study area, inadequate fund for the procurement of palm oil processing equipment was identified as one of the major problems in both Ikwerre and Etche local government area having $45(37.5 \%)$ and $40(30.5 \%)$ respectively. Scarcity of labour was identify as the least problem in the study area having $20(16.7 \%)$ and $15(11.5 \%)$ in Ikwerre and Etche local government areas respectively.

These problems faced the palm processors may have contributed to lack of expansion of the enterprise in the study area.

\section{CONCLUSION}

The results of the study revealed that small-scale palm oil processing in Ikwerre and Etche Local Government Areas of Rivers State was profitable. Cost of labour was higher in Ikwerre Local Government Area than in Etche local government area. Minimum cost of establishing a smallscale palm oil processing mill was about N873, 750.00. Inadequate fund is a major problem faced by palm oil processors hence most of them could not establish own processing mills because $45(37.5 \%)$ of the respondents admitted that inadequate fund was a major problem and in Etche LGA, 40 (30.5\%) also had problems of inadequate fund as a major problem of the palm oil milling enterprise as one of the major problems.

\section{RECOMMENDATIONS}

1) Government should extend construction of roads to the rural area by improving the condition of feeder roads which will ease transportation problems.

2) Fund should be made available by government agencies and financial institutions to small-scale palm oil processors by granting credit facilities to them, this will enable them purchase oil milling equipment.

3) Government should assist the processors by subsidizing cost of processing equipment.

4) Small-scale processors should form active cooperative to expand their scale of production.

5) Training workshops should be organized by government agencies, NGOs, private individuals on best practices and management of small scale palm oil mill enterprises in the study area

\section{REFERENCES}

Armstrong, Robert (1998). Palm Oil. The Australian National University, URL:

http//www.anu.edu.au/forestry/wood/nwfp/palm oil.html.

Carrer,R (2001). Over view of the oil Palm Issues, World Rainforest Movement, Uruguay. Pp 1-16. http://www.wrm.org.uy.plantations/material/oilpalm4.html

FAO (2005). Small-scale Palm Oil Processing in Africa, Corporate Document 
Journal of Agriculture and Social Research (JASR) Vol. 8, No. 2, 2008

Repository. www.fao.org/Docrep/05/YE335E/Y4355e $0_{3}$.htm.

Omoti,U (2004) Oil Palm Research at NIFOR, Nigeria. BUROTROP Bulletin 19: pp 43- 46. Omereji, G.O (2005) The Oil Palm Industry in Nigeria: cultivation, Processing and Trade. Mindex publishers,pp , Benin City.131-156

Rahman, A.A.A. (1998). "Malaysian Oil Palm Industry. Retrospect and Prospect". A paper presented at 1998 International Oil Palm Conference, Indonesia, $1 \& 2$.

Vogil, J.H (2002). A Palm oil mill in Oyo state, A draft proposal for private Venture, prepared for Government of Oyo State, Ibadan, pp 1-10. 